\title{
Field relationships, mineralogy and structural features of the Port Mouton pluton, southwestern Nova Scotia
}

\author{
S.L. (Woodend) Douma* \\ Department of Geology, Dalhousie University, Halifax, Nova Scotia B3H 3J5, Canada \\ Date Received November 30, 1991 \\ Date Accepted March 16, 1992
}

\begin{abstract}
The Port Mouton pluton (PMP) of southern Nova Scotia is a complex, peraluminous, post-tectonic granitoid body that is distinct from other plutons and batholiths of the Meguma Terrane. The pluton consists of ten units, which collectively range in composition from tonalite to trondhjemite, granodiorite, monzogranite, leucomonzogranite, aplite, pegmatite and lamprophyre.

The PMP evolved in three mafic to felsic cycles defined by the initial mafic end-members for each cycle (units 1,4 and 7). These three units are the most volumetrically abundant of the ten units and unit 1 is the oldest. Shoshonitic lamprophyres intruded mid-way through cycle II and were subsequently intruded by units in cycle III.

The PMP is at least $352 \mathrm{Ma}\left({ }^{40} \mathrm{Ar} /{ }^{9} \mathrm{Ar}\right)$ and is demonstrably younger than the regional metamorphism of $395 \mathrm{Ma}$. Two distinct foliations observed within the pluton occur only in units 1 and 4 . The foliation in unit 1 is perpendicular to the regional foliation of the country rocks and is probably of igneous origin. The local foliation in unit 4 , the origin of which remains unknown, is perpendicular to that in unit 1 and parallel to the regional foliation in the country rocks. Contacts of the PMP with the host metasedimentary rocks are predominantly sharp, although minor migmatization is present locally.
\end{abstract}

Le pluton de Port Mouton (PMP) du sud de la Nouvelle-Écosse est une masse granitique complexe, peralumineuse et post-tectonique, qui se distingue des autres plutons et batholites du terrain de Meguma. Le pluton consiste en dix unités, allant des tonalites aux trondhjemites, granodiorites, monzogranites, leucomonzogranites, aplites, pegmatites et lamprophyres.

L'évolution du PMP se divise en trois cycles mafiques à felsiques définis par les termes mafiques de chaque cycle (unités 1, 4 et 7). Ces trois unités sont les plus abondantes et l'unité 1 est la plus ancienne. Des lamprophyres shoshonitiques se sont mis en place vers le milieu du cycle II et ont été subséquemment recoupés par les unités du cycle III.

Le PMP a un âge minimum de $352 \mathrm{Ma}\left({ }^{40} \mathrm{Ar} /{ }^{\circ} \mathrm{Ar}\right)$ mais prédate le métamorphisme régional daté à $395 \mathrm{Ma}$. Les deux foliations distinctes observées dans le pluton ne se retrouvent que dans les unités 1 et 4 . La foliation dans l'unité 1 est perpendiculaire à la foliation régionale des roches encaissantes et est probablement d'origine ignée. La foliation locale dans l'unité 4 , dont l'origine reste obscure, est perpendiculaire à celle de l'unité 1 et est parallèle à la foliation régionale des roches encaissantes. Les contacts du PMP avec les roches métasédimentaires encaissantes sont principalement nets, bien qu'il y ait de la migmatisation locale.

[Traduit par le journal]

\section{INTRODUCTION}

The purpose of this paper to present the initial results of a petrological study of the Port Mouton pluton (PMP), a peraluminous granitoid pluton located in the southern Meguma Terrane of Nova Scotia (Fig. 1). In this study the field relationships of the PMP, definition of the units comprising the PMP, some mineral chemistry of the major silicate phases and the structure of the PMP are presented. Although an extensive geochemical data base exists for the PMP (Douma, 1988), these data will be presented elsewhere. The PMP is characterized by a diverse assemblage of granitic rocks rang-

*present address: 423C Wentworth Avenue, Ottawa, Ontario K2B $5 \mathrm{~J} 7$ ing in composition from tonalite to pegmatite. It intruded high-grade metamorphic rocks of the Lower Paleozoic Meguma Group and, because of its diverse petrological assemblage, potentially offers insight into the origin of granites in the Meguma Terrane. Mapping of the PMP and the surrounding metasedimentary rocks of the Meguma Group was completed during the summer of 1985 (Hope and Woodend, 1986; Hope, 1987) and follow-up petrological studies are summarized in Douma (1988).

In the Late Devonian to Early Carboniferous, the Meguma Group was intruded by a number of peraluminous granitoid plutons (Clarke and Halliday, 1980; Dallmeyer and Keppie, 1986; Elias, 1986; Reynolds et al., 1981), the largest of which is the South Mountain Batholith (SMB). The SMB and other peraluminous Meguma Zone plutons have been the 


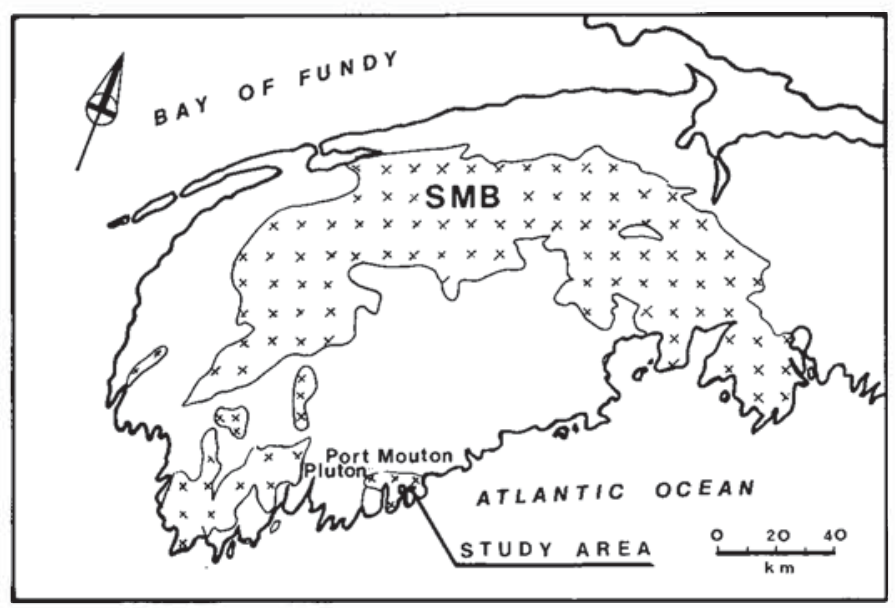

Fig. 1. Outline of southern Nova Scotia showing the location of the Port Mouton pluton and South Mountain Batholith (SMB).

object of extensive geological, geochemical and geophysical investigations over the past two decades. This study provides data on which to base interpretations of the origin of these granites and represents the first comprehensive study of this particular pluton. Aspects to be addressed include: (1) the geological outline of the pluton as revealed by new mapping; (2) a detailed description of the ten units comprising the PMP and standardization of the nomenclature of the PMP so that it can be compared with other granitoid bodies in the Meguma Zone; (3) mineralogy of the pluton; and (4) the structure of the PMP and the surrounding country rocks of the Meguma Group.

\section{General Comments and Previous Work}

The PMP, located $12 \mathrm{~km}$ southwest of the town of Liverpool on the southern shore of Nova Scotia, covers an area of about $160 \mathrm{~km}^{2}$. The pluton outcrops south of Highway 103, at Port Mouton Island, White Point, Hunts Point, Mouton Head, Black Point, St. Catherines River Beach, Port Joli Harbour, Haley Lake and at the head of Port LeHebert Harbour (Fig. 2). It is best exposed along shorelines, with sparse, small outcrops in the interior of the pluton and along the northern and western contacts. Small brooks permit access to the northern part of the pluton.

The PMP was first noted and named by Fairbault in 1913. Taylor (1967) completed a reconnaissance geological map of the Shelburne area in which he noted that: (1) the PMP (referred to as the Port Joli pluton in his report) intruded metasedimentary rocks of the Meguma Group and that contacts of the pluton with the sedimentary rocks were "chiefly sharp but in part consisting of a mixed zone of biotite quartzite and granodiorite"; (2) migmatites crop out along the shore at White Point and west of White Point; (3) the bulk of the pluton is granodiorite; and (4) the PMP is primarily massive, but in places (i.e., east side of Port Joli Bay) preferred orientation of biotite imparts a distinct foliation and sedimentary inclusions also show a preferred orientation.
Detailed descriptions of beryl-bearing pegmatites of the PMP were made by Oldale (1959); Taylor (1967) also noted the occurrence of beryl in the pegmatites. Recent detailed study of a pegmatite in the PMP was completed by MacDonald (1988).

De Albuquerque (1977) and Smith (1979) provided some geochemical data and general petrographic descriptions of the PMP, and reconnaissance $\mathrm{O}$ and $\mathrm{S}$ whole rock isotopic data were provided by Longstaffe et al. (1979) and Kubilius (1983). Radiometric dating of the PMP includes: (1) a Rb-Sr biotite date of $326 \pm 5 \mathrm{Ma}$ (Fairbairn et al., 1960); (2) a 3point whole rock $\mathrm{Rb}-\mathrm{Sr}$ isochron age of $349 \pm 15 \mathrm{Ma}$ (Cormier and Smith, 1973); and (3) ${ }^{40} \mathrm{Ar}{ }^{99} \mathrm{Ar}$ plateau ages for mica of $297 \pm 8 \mathrm{Ma}$ and $300 \pm 8 \mathrm{Ma}$ obtained by Reynolds $\mathrm{et}$ al. (1981) and 255 to $321 \mathrm{Ma}(\mathrm{n}=3)$ reported in Elias (1986). In addition, Elias (1986) obtained a "staircase profile" for a muscovite with a maximum age of $352 \mathrm{Ma}$.

A structural study of the fine-scale igneous layering was conducted by Maksaev (1986), and Hope (1987) studied the contact metamorphic aureole associated with the PMP. Detailed work on a migmatite near the northeast margin of the PMP was completed by Merrett (1987).

The PMP has been assessed for its beryllium, tin, tungsten and uranium potential over the years by numerous mining companies, but nothing of economic value has yet been discovered.

\section{Field Relationships}

\section{General Statement}

The PMP is elliptical in plan view with axes approximately $20 \mathrm{~km}$ (NE-SW) by $9 \mathrm{~km}$. Ten distinct units are recognized based on cross-cutting relationships. Observations are heavily based on the excellent exposures along the coast versus poor exposure along the northwestern contact and in the interior of the pluton.

The pluton is locally very heterogeneous and, within a $100 \mathrm{~m}^{2}$ area, up to seven units have been mapped. Because of this heterogeneity, only two distinct units can be displayed at a scale of 1:50,000 (Fig. 2). Unit 1 consists of coarse-grained, foliated biotite tonalite and occurs around the perimeter of the pluton. This unit makes up approximately $15 \%$ of the pluton and is the oldest intrusive phase exposed. In the central part of the pluton the predominant lithology is granodiorite to monzogranite (unit 4 ), comprising about $50 \%$ of the intrusive material in the pluton. Coded pie diagrams on Figure 2 represent the relative abundances of the units within the vicinity of each symbol.

With the exception of the pegmatitic unit 9, all units in the PMP have been examined petrologically. Stained slabs from 109 samples were point counted and classified according to Streckeisen (1976; see Fig. 3). Table 1 summarises the field descriptions of the ten units. Some units with a wide variation in composition (e.g., ranging from tonalite to granodiorite to monzogranite) are combined into a single unit because of their similar field relations. 

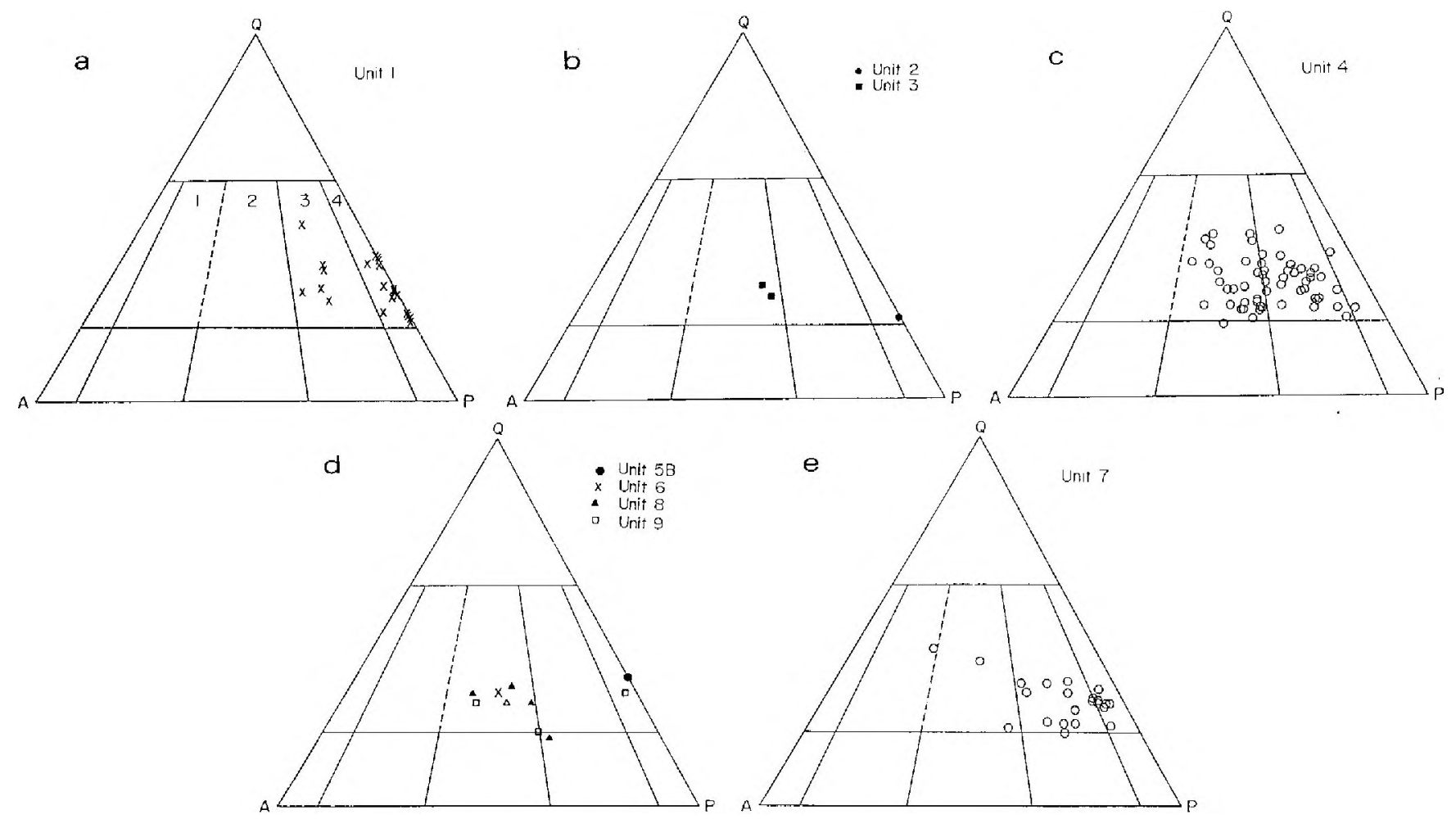

Fig. 3. Ternary (QAP) quartz-alkali feldspar-plagioclase diagrams showing the results of modal analyses of samples from the different units comprising the Port Mouton pluton. Numbers refer to names of the following rock types (after Streckeisen, 1976): 1 - syenogranite, 2 - monzogranite, 3 - granodiorite, 4 - tonalite.

\section{Unit Descriptions}

\section{Unit 1, biotite tonalite}

Unit 1 is a moderately well-foliated, coarse-grained, biotite-rich (avg. $15 \%$ biotite; $23 \%$ near contacts with the country rock) tonalite (Fig. 3); composition changes from tonalite (dominant in the area shown as unit 1 on Fig. 2) to granodiorite toward the interior of the pluton. In addition to the major minerals, other phases include muscovite (1-11\%), apatite and zircon. Garnet, observed in one sample, is probably xenocrystic from garnet-rich pelitic horizons in the nearby country rock.

Unit 1 comprises about $15 \%$ of the PMP and crops out mainly along the southern margin of the pluton; it is the unit of the pluton that is most commonly in direct contact with the Meguma Group. The contacts between unit 1 and the country rocks are typically sharp, al though at three localities (Isaac's Harbour, $0.5 \mathrm{~km}$ north of Forbes Point, and at Scotch Point) abundant injection migmatites formed. Migmatites are prominent $1 \mathrm{~km}$ east of Summerville Beach and at White Point, where the tonalite has developed a subporphyritic texture with plagioclase phenocrysts up to $8 \mathrm{~mm}$ long. Biotite tonalite dykes intrude along bedding planes of the country rock and are prominent at the migmatitic contacts. Many xenoliths of the country rocks have undergone ductile deformation and show evidence of anatexis in the formation of ptygmatically folded granitic bands (Merrett, 1987). The injection gneiss contacts are similar to the migmatite contacts, but lack leucosome and ptygmatically folded granitic bands.

The types and percentages of xenoliths in unit 1 vary as a function of their distance from the edge of the pluton. Near the contact unit 1 contains abundant xenoliths of psammitic and pelitic composition whereas xenoliths of unit 4 are less abundant. At distances greater than $500 \mathrm{~m}$ from the contact, unit 1 contains approximately $2 \%$ fine-grained, biotite-rich mafic inclusions. These inclusions are typically rounded and elliptical to circular in shape; they range in composition from hornfels of the Meguma Group to biotite schlieren and ghost enclaves of unknown origin. Typically the inclusions are finer grained than the host tonalite or granodiorite and have a higher modal percentage of biotite. Locally, feldspar porphyroblasts occur in the inclusions. No microgranitoid enclaves (as described by Vernon, 1984) were identified in this unit, although xenoliths of unit 1 commonly occur in the later units. In particular, large 10 to $15 \mathrm{~m} \times 10 \mathrm{~m}$ blocks of unit 1 occur in the younger, medium-grained, biotite-muscovite granodiorite and monzogranite of unit 4. The biotite foliation seen in unit 1 is retained in the xenoliths, but occurs at high angles to the regional foliation, indicating that the blocks have been rotated.

Orientations of metasedimentary xenoliths and biotite schlieren, collectively from units 1 and 4 , are shown on Figure 4a. The irregular, wavy, biotite-rich schlieren in both units 1 and 4 are considered to be passive schlieren (Trent, 1981) and appear to have been passengers in the moving 
Table 1. Summary of units in the Port Mouton pluton.

\begin{tabular}{ll}
$\begin{array}{l}\text { Unit \# } \\
\text { (Area of intrusion) }\end{array}$ & Description of unit \\
\hline $\begin{array}{l}9 \\
(20-25 \%)\end{array}$ & $\begin{array}{l}\text { fine-grained aplite }( \pm \text { garnet, biotite, muscovite) and pegmatite } \pm \text { biotite } \\
\text { tourmaline, beryl, gamet, fluorapatite) }\end{array}$ \\
\hline $\begin{array}{l}\text { fine- to medium-grained equigranular biotite-muscovite leucomonzogranite } \\
\text { intimately associated with unit } 9\end{array}$ \\
$\begin{array}{l}\text { fine-grained equigranular, rarely porphyritic, mesocratic to melanocratic } \\
\text { biotite-muscovite tonalite, granodiorite, rarely }(5-10 \%) \text { monzogranite. }\end{array}$
\end{tabular}

FORM and PERCENTAGE of unit 7 (not in order of age)

$1(40 \%) \quad$ pods, irregular meandering dykes

$2(30 \%) \quad$ dyke swarms with rounded biotite-rich xenoliths

$3(<10 \%) \quad$ dykes associated with pegmatites

$4(1 \%) \quad$ dykes with rounded biotite clots

$5(20 \%) \quad$ planar dykes with sharp contacts

pegmatite, aplite and medium-grained equigranular leucomonzogranites ( \pm biotite, muscovite, garnet)

\begin{tabular}{ll}
\hline $\begin{array}{l}\text { 5B } \\
(<1 \%)\end{array}$ & $\begin{array}{l}\text { fine-grained melanocratic biotite-muscovite tonalite breccia, with } 50 \% \\
\text { clasts. }\end{array}$ \\
\hline $\begin{array}{l}\text { 5A } \\
(<1 \%)\end{array}$ & $\begin{array}{l}\text { phlogopite and amphibole-rich lamprophyre dykes (younger than older } \\
\text { than } 7)\end{array}$ \\
\hline $\begin{array}{l}(50 \%) \\
3 \\
(1 \%)\end{array}$ & $\begin{array}{l}\text { medium-grained, equigranular, biotite-muscovite granodiorite to } \\
\text { monzogranite }\end{array}$ \\
\hline $\begin{array}{l}(<1 \%) \\
1\end{array}$ & medium- to fine-grained, equigranular, biotite-muscovite leucomonzogranite \\
\hline
\end{tabular}

Note:

Grain size: fine $<1 \mathrm{~mm}$, medium 1 to $4 \mathrm{~mm}$, coarse $>4 \mathrm{~mm}$

Colour: leucocratic - mafic mineral content $<5 \%$, mesocratic - mafic mineral content 5 to $20 \%$, melanocratic mafic mineral content $>20 \%$.

magma or crystal mush of enclosed rock. The maximum concentration of planes on the plot is about $140^{\circ}$, dipping moderately to the southwest.

Foliation in unit 1 is displayed as a mild parallel align- 


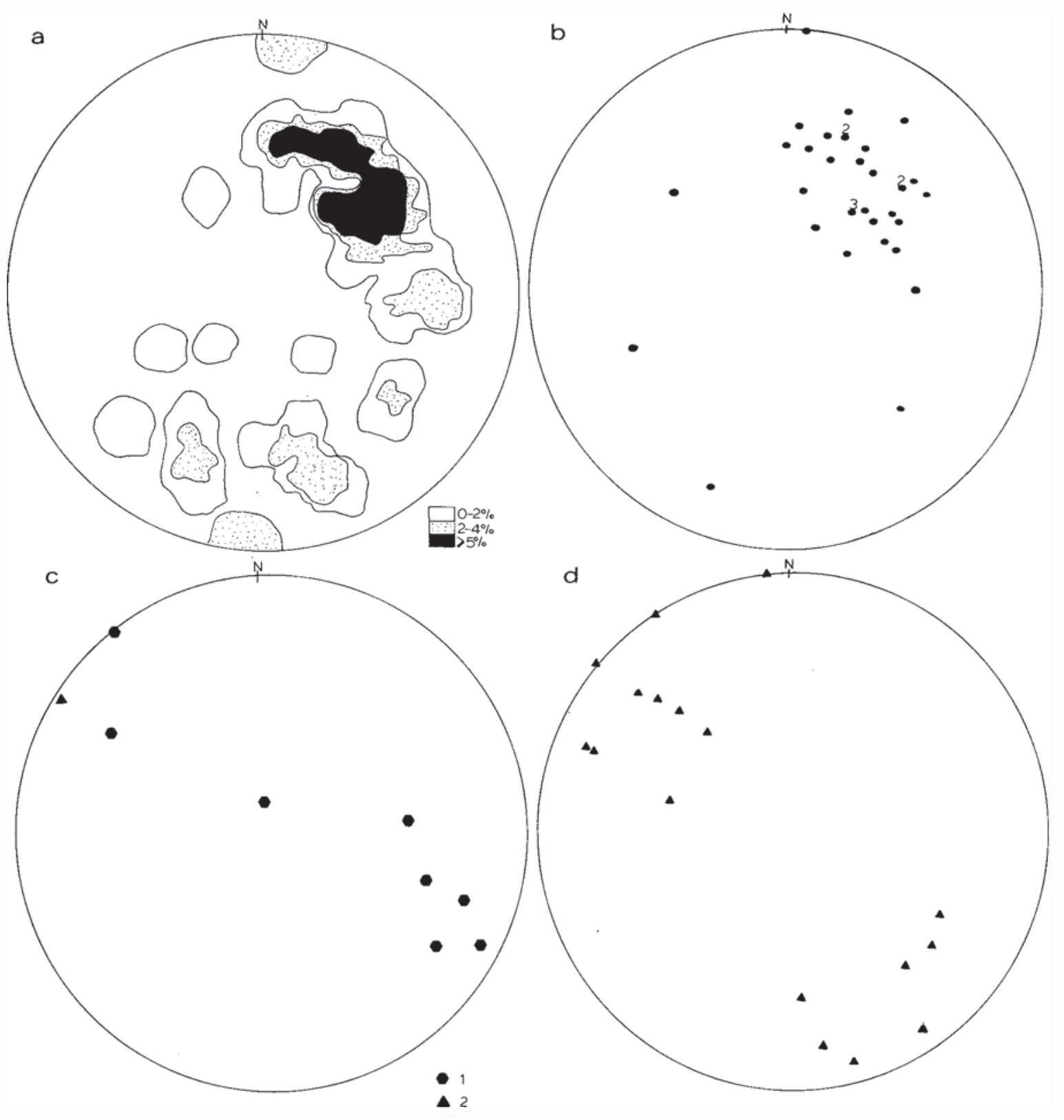

Fig. 4. Structural data (poles to planes) for different units of the Port Mouton pluton plotted in Schmidt stereographic projections. (a) 48 orientations of xenoliths and schlieren in units 1 and 4 contoured in $1 \%$ area; (b) 39 orientations of foliations in unit 1 ; (c) orientation of banding in units 1 (hexagons) and 4 (triangle); (d) 17 orientations of foliation in unit 4.

ment of biotite and is commonly visible only on fresh outcrop surfaces. It is moderately well developed in the vicinity of the contact with the country rocks, but poorly developed (or absent) in the interior of the pluton. An equal area stereographic projection of foliations from unit 1 , predominantly from outcrops near St. Catherines River Bay and within $1 \mathrm{~km}$ of the contact with the Meguma Group, shows a concentration near $108^{\circ} / 60^{\circ} \mathrm{SW}$ (Fig. 4b). This orientation is almost perpendicular to the $030^{\circ}$ to $040^{\circ}$ regional foliation in the country rock (see below) and may reflect rotation of the country rock as a result of the intrusion of the pluton (i.e., a block of country rock is suspended by the granitoid intrusion).

\section{Unit 2, trondhjemite}

Unit 2 is represented by a $2 \mathrm{~m}$ wide, coarse-grained (5-8 $\mathrm{mm})$, leucocratic trondhjemite dyke in unit 1 near Black Point (Fig. 2). Its contact with the tonalite is sharp and it contains a large tonalite xenolith. Although unit 2 consists of a single dyke, its clear cross-cutting relationship with unit 1 indicates that it is distinct from unit 1 , however, its relationship to other units is not known. The trondhjemite contains euhedral and subhedral plagioclase $(69 \%)$, quartz $(20 \%)$, biotite $(8 \%)$ and muscovite $(3 \%)$. In places, the margins are biotite-rich and thin biotite schlieren, up to $1 \mathrm{~m}$ long, are aligned parallel to the contacts. 


\section{Unit 3, monzogranite}

Unit 3, a fine- to medium-grained, in part leucocratic, biotite-muscovite monzogranite (Fig. 3), makes up about $1 \%$ of the pluton and occurs as inclusions and wispy bands in unit 4. In addition to the essential mineral constituents, it contains $<10 \%$ combined biotite and muscovite.

\section{Unit 4, granodiorite to monzogranite}

Unit 4 is the dominant unit of the pluton, comprising about half of the body. It is mainly an equigranular, mediumgrained, mesocratic, biotite-muscovite granodiorite to monzogranite (Fig. 3) that, in places, displays a mild foliation. The grain size increases towards the interior of the pluton where it is the dominant phase. In addition to the major mineralogy, it contains muscovite (1-14\%, avg. $5 \%$ ), biotite (3-26\%, avg. $10 \%)$ and accessory apatite, zircon and rare rutile. The dominant texture is hypidiomorphic granular, commonly subporphyritic, with phenocrysts of inclusionrich microcline and rarely plagioclase.

Contacts of unit 4 with the country rock are sharp, but contacts with unit 1 are sharp only near the periphery of the pluton and become less distinct toward the interior. In the northeast section of the pluton, rocks of unit 4 have truncated migmatitic banding. Unit 4 appears to be spatially associated with unit 3 , where unit 3 occurs as alternating flow bands within unit 4 and in places unit 4 contains inclusions of unit 3.

Where they are observed within the same outcrop, the main features used to distinguish unit 4 from the biotite tonalite of unit 1 are: (1) the finer grain size of unit 4 ; (2) foliation in unit 4 is less well defined; (3) muscovite is more abundant in unit 4 than in unit 1 ; (4) inclusions of unit 1 are commonly found in unit 4 ; (5) dykes of unit 4 cut dykes of unit 1 ; and (6) tonalitic compositions are absent in unit 4 and no monzogranitic phases are present in unit 1 . However, in some places unequivocal identification of unit 4 is difficult because of its variable appearance (modal mineral abundances of units 1 and 4 overlap; Fig. 3) and because in many areas, cross-cutting relationships between the numerous dykes are so complex that correlation with any one unit is impossible without extensive geochemical work. In some outcrops only one unit is exposed, making identification on the basis of cross-cutting relationships impossible, and in the interior of the pluton the differences in texture, grain size and modal mineralogy between units 1 and 4 are less distinct. In the interior of the pluton unit 1 is mainly a coarse-grained, mesocratic, biotite-muscovite granodiorite, whereas unit 4 is a medium-grained, mesocratic, biotite-muscovite granodiorite to monzogranite. The most reliable criteria for distinguishing units 1 and 4 , in the interior of the pluton, are crosscutting relationships and the presence of inclusions of unit 1 in unit 4.

A variety of xenoliths occur in unit 4 , including enclaves of granitoid, metasedimentary and unknown affinity (possi- bly digested metasedimentary material). The inclusions represent tonalite from unit 1 and are most abundant proximal to the contact with unit 1 where they occur as blocks up to $10 \mathrm{~m}$ $x 10 \mathrm{~m}$. Approaching the interior of the pluton, inclusions of unit 1 become smaller, less abundant and rounded. Unit 1 appears to have crystallized and become brittle prior to emplacement of unit 4 because the xenoliths of this unit are angular. In addition, a well-developed foliation occurs in these xenoliths at oblique angles to the poorly-developed foliation in unit 4 . Locally, unit 4 also contains rounded to convoluted inclusions of leucomonzogranite (unit 3) and xenoliths of metasedimentary rocks. In addition, inclusions of unknown origin are ubiquitous throughout the unit. They have a wide range in composition including: (1) fine-grained, biotite-rich, quartzo-feldspathic inclusions; (2) potassic feldspar porphyry inclusions; (3) 'granitized' biotite-rich quartzofeldspathic inclusions; and (4) biotite-rich inclusions. These inclusions are rounded and range in length from 2 to 70 $\mathrm{cm}$. In the interior of the pluton, large blocks ( $35 \mathrm{~m}$ by $0.5-3$ $\mathrm{m}$ ) of metasedimentary country rock occur in unit 4 . Biotiterich schlieren $(1-3 \mathrm{~m}$ by $0.25 \mathrm{~m})$ are ubiquitous in the pluton.

Rarely, unit 4 displays coarse $(30-150 \mathrm{~cm})$ and fine $(<10$ $\mathrm{mm}$ ) bands of interlayered, medium-grained, melanocratic, biotite-muscovite granodiorite and mesocratic, biotite-muscovite monzogranite. The bands trend approximately $020^{\circ}$ to $040^{\circ}$, have variable dips (Fig. 4c) and parallel the regional foliation in the country rock. Maksaev (1986) studied the nature of this banding on Port Mouton Island and concluded that the fine and coarse banding formed contemporaneously as a result of stresses imposed during the crystallization and cooling of the PMP.

Foliation observed in unit 4 is sporadic and varies in intensity. It is produced by an alignment of biotite and muscovite, but is difficult to measure in many places because of the lack of planar development. Only eighteen measurements were recorded and their trend is similar to the regional foliation (Fig. 4d).

\section{Unit 5A, lamprophyre}

Unit 5A, a fine- to coarse-grained, phlogopite-amphibole lamprophyre has only been observed at two locations in the PMP. Although unit 5A consists of only two dykes, its clear intermediate relationship to the other units justify it being designated as a unit.

At Forbes Point a vertical dyke (maximum $6 \mathrm{~m}$ width) has intruded tonalite of unit 1 and monzogranite of unit 4 . The interior of the dyke is coarse-grained, panidiomorphic, phlogopite- and actinolite-rich with subordinate sphene, apatite, plagioclase and opaque minerals. A second zone, consisting of 10 to $20 \mathrm{~cm}$ long lenses that are most abundant near the dyke margins, contains zoned plagioclase (20\%) phenocrysts $(1-5 \mathrm{~mm})$ and subordinate quartz in a fine-grained, actinolitic hornblende matrix; subordinate mineralogy is similar to the interior zone. The third zone is 3 to $4 \mathrm{~cm}$ wide and at the contact between the lamprophyre and the host granite. It 
consists of a coarse-grained mass of amphibole, plagioclase and biotite; the amphibole is oriented perpendicular to the contact.

At MacLeods Cove a second mafic dyke $(8-10 \mathrm{~m}$ by $2 \mathrm{~m})$ is in contact with the tonalite breccia of unit 5B. This dyke is not zoned like the other dyke and has been altered by subsequent plutonic activity, but the mineralogy is similar albeit lacking phenocrystic phases. No distinct contact aureole is associated with the dyke. Late-stage, fine-grained tonalite to granodiorite dykes of unit 7 have cut the lamprophyric dyke.

\section{Unit 5B, tonalite breccia}

A breccia dyke composed of fine-grained, melanocratic, biotite-muscovite tonalite (Fig. 3 ) is exposed at the southern contact of the pluton. The breccia contains up to $50 \%$ angular- to subangular inclusions $(5-50 \mathrm{~cm})$ of cloudy white quartz, metasedimentary country rock and tonalite to granodiorite. The matrix is hypidiomorphic-granular and consists of plagioclase $(46 \%)$, quartz (23\%), biotite (26\%), muscovite $(4 \%)$ and accessory amounts of apatite, zircon and xenocrystic garnet.

The breccia dyke was intruded as a meandering dyke of variable width along the contact between unit 1 and the country rock. The dyke is cut by dykes of fine-grained biotite tonalite (unit 7), fine-grained leucocratic monzogranite (unit 8 ) and pegmatites and aplites (unit 9).

The contact between units 1 and 5B is sharp, but its relationship to unit 5A, also occurring in the outcrop, is unclear.

\section{Unit 6, leucocratic dykes}

Unit 6 includes fine-grained aplite dykes ( \pm garnet), medium-grained leucomonzogranite dykes ( \pm garnet) and associated pegmatite dykes (Fig. 3). The leucomonzogranite dykes are typically banded and display a hypidiomorphic granular texture and, in addition to the essential constituents, contain biotite (to $6 \%$ ), muscovite $(2-4 \%)$ and accessory zircon and garnet. The unit comprises $<1 \%$ of the pluton and is similar in composition to units 8 and 9 , but is distinguished from them by being intruded by unit 7 .

\section{Unit 7, fine-grained tonalite to granodiorite}

Unit 7, comprising 5 to $10 \%$ of the PMP, varies in composition from biotite-muscovite tonalite to granodiorite and, more rarely, to monzogranite (Fig. 3) with 6 to $27 \%$ biotite, up to $8 \%$ muscovite and accessory apatite and zircon. It is mainly a fine-grained, hypidiomorphic granular rock, although medium-grained and plagioclase-phyric varieties exist. The compositional variability indicates a number of compositions are included in the unit, but because of its systematic relationship to well-documented older and younger units, it is considered as a single unit.

At least five morphological subdivisions of unit 7 can be described: (1) pods and/or irregular meandering dykes com- prising ca. $40 \%$ of unit 7 ; (2) inclusion-rich dyke swarms comprising $30 \%$ of unit 7 . Swarms of dykes (to $25 \mathrm{~m}$ width) contain up to $20 \%$ rounded inclusions $(10-40 \mathrm{~cm})$ of finegrained quartzofeldspathic material (probably psammitic country rock), fine-grained biotite-rich material and, more rarely, coarse-grained granitoid lithologies; (3) dykes intimately associated with zoned pegmatites of unit 9; these comprise $10 \%$ of unit 7 . The dykes and pegmatites appear to have been emplacement synchronously; (4) dykes containing rounded, 2 to $5 \mathrm{~cm}$ biotite clots $(<1 \%$ of unit 7$)$. At one locality the dyke is $5 \mathrm{~m}$ wide and at another outcrops for almost $1 \mathrm{~km}$; and (5) fine-grained biotite (5-20\%) tonalite/ granodiorite dykes comprise $20 \%$ of unit 7 . The dykes may contain inclusions $(<10 \%)$ of the adjacent country rocks.

\section{Unit 8, monzogranite}

Unit 8 is a fine- to medium-grained, equigranular, leucocratic, biotite-muscovite monzogranite (Fig. 3) which comprises less than $10 \%$ of the pluton; biotite is up to $6 \%$ and muscovite 2 to $4 \%$; rare garnet is present where pegmatites of unit 9 are close. Unit 8 dykes are generally homogeneous, cut older pegmatites, are often intimately associated with the zoned pegmatites and aplites of unit 9 , and are more abundant along the margins of the pluton where, together with dykes of unit 9 , they have invaded the country rocks.

\section{Unit 9, pegmatite and aplite}

Unit 9, comprising 20 to $25 \%$ of the PMP, is the youngest intrusive phase and includes fine-grained, garnet-rich aplite and texturally and compositionally variable pegmatite (Fig. 3 ). The aplite consists of quartz (18-27\%), plagioclase (31$59 \%)$, microcline $(3-36 \%)$, muscovite $(3-10 \%)$, biotite (1$5 \%)$ and accessory garnet. The pegmatite contains quartz $(<1$ $\mathrm{cm}-1.5 \mathrm{~m}$ ), perthitic feldspar, plagioclase and muscovite with accessory biotite, tourmaline, garnet, fluorapatite, beryl and rare molybdenite. Pegmatite dykes are abundant throughout the pluton, particularly at the contact with the country rocks. Unit 9 is commonly associated with units 7 and 8; the three units often forming zoned pegmatite complexes attaining $>7$ $\mathrm{m}$ width and tens of metres length. Dykes of fine-grained aplite \pm pegmatite may be followed for $>100 \mathrm{~m}$ into country rock. Pegmatite and aplite dyke orientations in the PMP appear random (Fig. 5a,b), although this may be a function of the limited data set. There appears to be no significant difference in dyke orientation between wider (greater than 1 m) and narrower pegmatite dykes (Fig. 5b,c).

\section{Mineral Chemistry}

\section{Introduction}

Compositions of biotite, muscovite, garnet, amphibole and plagioclase were determined on the JEOL 733 Superprobe at Dalhousie University using a combined wavelengthand energy-dispersive analytical technique. Data reduction 

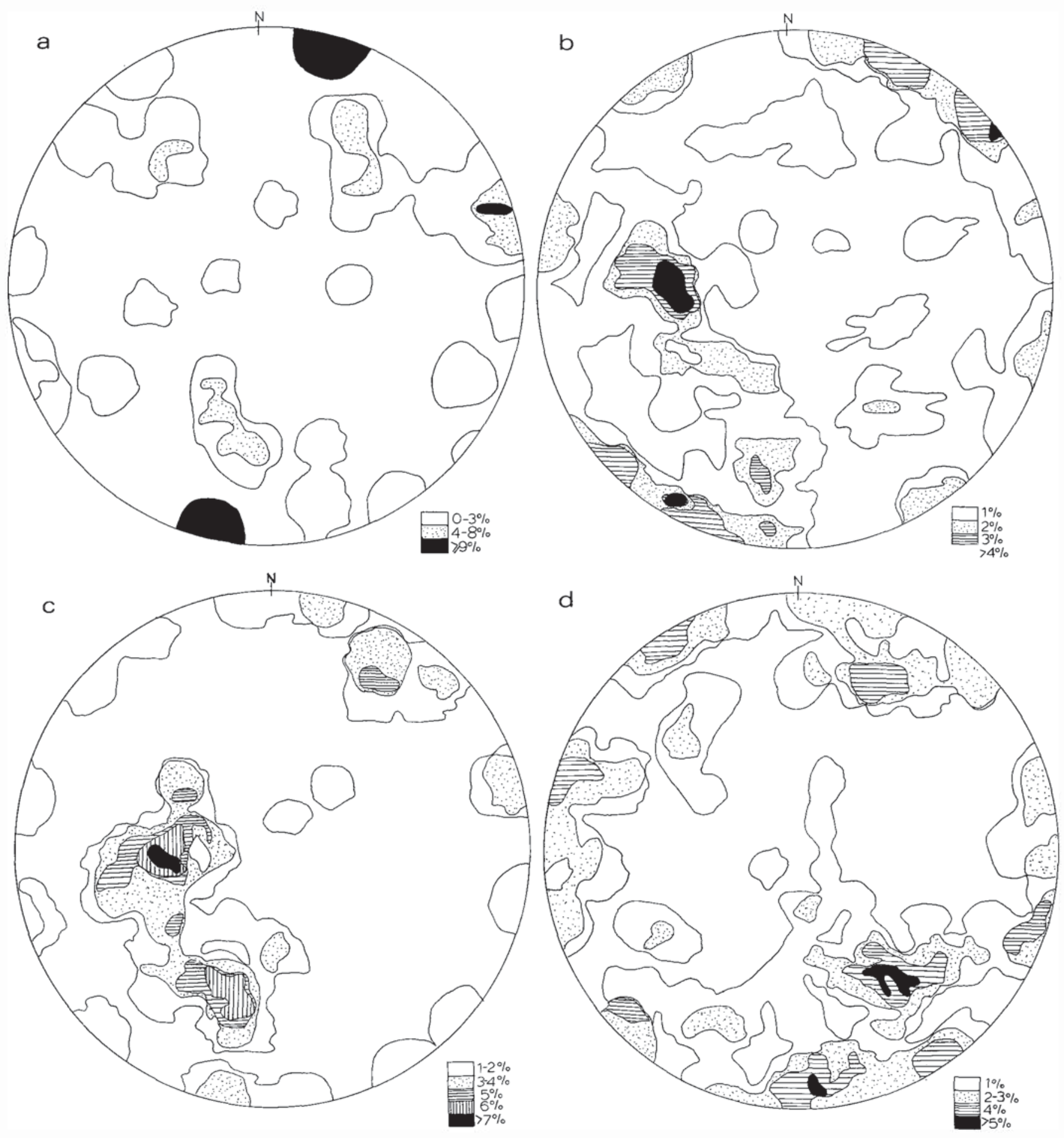

Fig. 5. Structural data (plotted as poles to planes) for different units of the Port Mouton pluton plotted in Schmidt stereographic projections. All diagrams contoured for $1 \%$ area. (a) 31 orientations of aplite dykes; (b) 256 orientations for pegmatite dykes $<1 \mathrm{~m}$ width; (c) 53 orientations of pegmatites $>1 \mathrm{~m}$ width; (d) 67 orientations of granite veins of units 4,5 and 8 .

of raw counts to wt. \%o of oxides was done using the ZAF software program. Details of the analyses and a complete data set are found in Douma (1988).

\section{Biotite}

Biotite is abundant in units 1, 4 and 7 of the PMP and subordinate in units $2,3,6,8$ and 9 . The lamprophyric dykes of unit $5 \mathrm{~A}$ contain abundant phlogopitic biotite. On a plot of ${ }^{i v} \mathrm{Al}$ versus $\mathrm{Fe}^{\mathrm{T}} /\left(\mathrm{Fe}^{\mathrm{T}}+\mathrm{Mg}\right.$ ) (Fig. 6a), biotite from unit $5 \mathrm{~A}$ plots close to the phlogopite end member in contrast to the other biotite compositions which plot in the region of higher iv $\mathrm{Al}$ and $\mathrm{Fe}^{\mathrm{T}} /\left(\mathrm{Fe}^{\mathrm{T}}+\mathrm{Mg}\right)$ ratios towards the siderophyllite-annite join. Based on Figure $6 a$, the following conclusions are made 

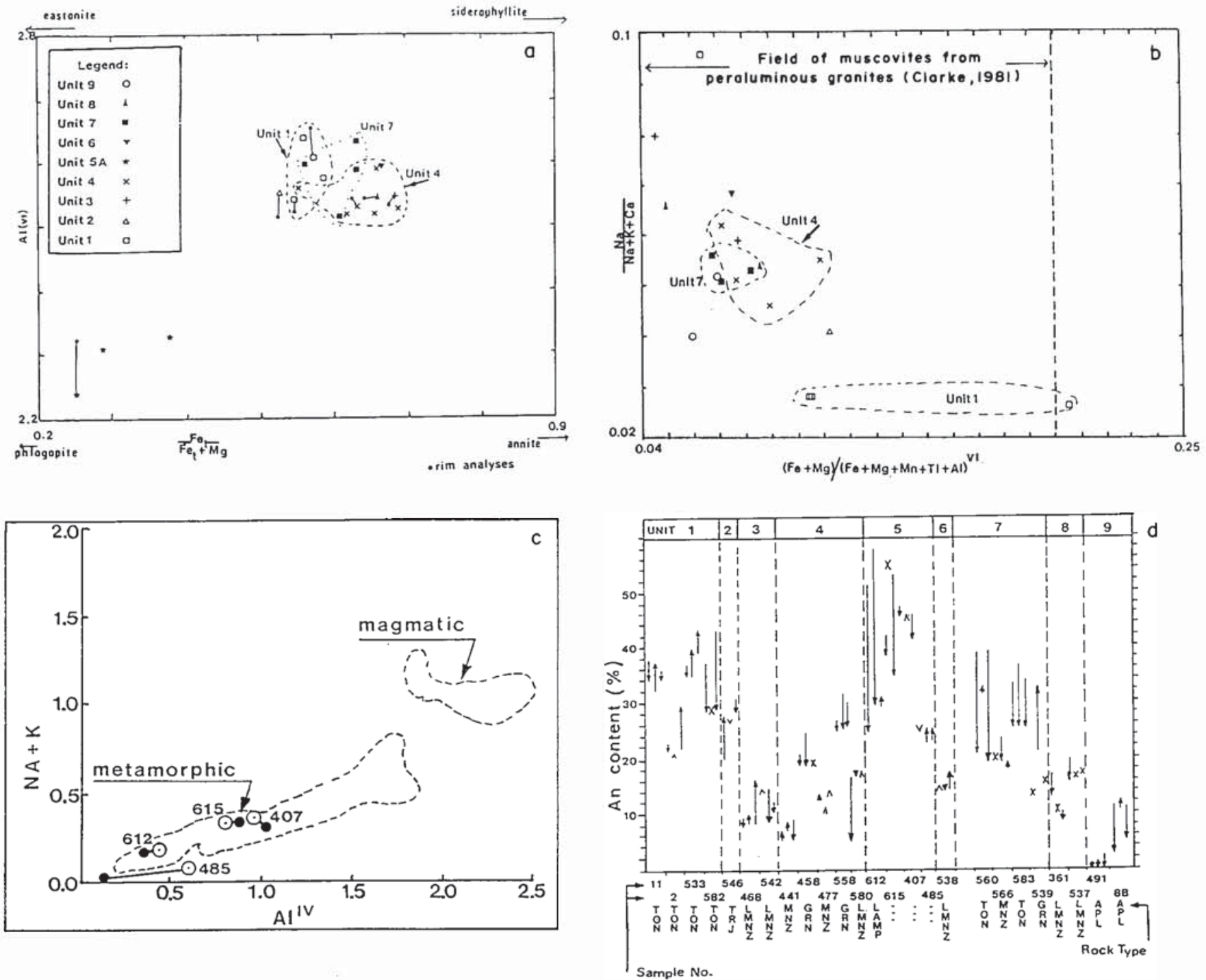

Fig. 6. Mineral chemistry for the Port Mouton pluton (see Douma, 1988 for the listing of original data). (a) $\mathrm{Al}^{\mathrm{iv}}$ versus $\mathrm{Fe}^{\mathrm{T}} /\left(\mathrm{Fe}^{\mathrm{T}}+\mathrm{Mg}\right.$ ) for biotite from all units of the pluton. Note that the results for unit $5 \mathrm{~A}$ (lamprophyre) plot in a separate part of the diagram. (b) Na/ $(\mathrm{Na}+\mathrm{K}+\mathrm{Ca})$ versus $(\mathrm{Fe}+\mathrm{Mg}) /(\mathrm{Fe}+\mathrm{Mg}+\mathrm{Mn}+\mathrm{Ti}+\mathrm{Al})$ for muscovite from all units of the pluton. Field for muscovite compositions from peraluminous granites is from Clarke (1981). (c) Fields for metamorphic and magmatic amphibole compositions from the St. Anthony Complex, New foundland (Jamieson, 1981). The results for analyses from the lamprophyres are labelled $(612,615,407,485)$; core (open circle) and rim (closed circle) compositions are joined by a tie line. (d) Plagioclase compositions (measured as mole \% An) along the vertical axis for all the units in the pluton. Arrow denotes the direction of zoning (i.e., down is normal and up is reverse). Abbreviations: APL - aplite, LMNZ - leucomonzogranite, GRN - granodiorite, TON - tonalite, MNZ - monzogranite, TRJ - trondhjemite.

regarding biotite compositions of the PMP: (1) biotites in units 6 and 8 are comparable in composition to those in unit 4; (2) biotites from units 1,4 and 7 have very similar ${ }^{\text {iv }} \mathrm{Al}$ and $\mathrm{Fe}^{\mathrm{T}} /\left(\mathrm{Fe}^{\mathrm{T}}+\mathrm{Mg}\right)$ values, although there is a progressive increase in the average $\mathrm{Fe}^{\mathrm{T}} /\left(\mathrm{Fe}^{\mathrm{T}}+\mathrm{Mg}\right)$ ratio from unit 1 , to 7 to 4 ; and (3) the composition of biotite from the trondhjemite of unit 2 is comparable to that in unit 1.

$\mathrm{Fe}^{\mathrm{T}} /\left(\mathrm{Fe}^{\mathrm{T}}+\mathrm{Mg}\right)$ in biotite has been used in the SMB as an indicator of differentiation (Stallard, 1975) where it was found to increase with differentiation. Applying this ratio to the PMP, it can be concluded that all units are more differentiated than the lamprophyres of unit $5 \mathrm{~A}$, that unit 4 is more evolved than units 1 and 7 and, finally, that unit 7 is more evolved than unit 1 .

\section{Muscovite}

Muscovite in the PMP granitoid rocks occurs replacing feldspar, intergrown with and replacing biotite, and as large subhedral grains overgrowing the quartz-feldspar matrix. According to Clarke (1981), muscovite compositions from peraluminous granitoid rocks have values of $\left[\left(\mathrm{Fe}^{\mathrm{T}}+\mathrm{Mg}\right) /\right.$ $\left.\left(\mathrm{Fe}^{\mathrm{T}}+\mathrm{Mg}+\mathrm{Mn}+\mathrm{Ti}+\mathrm{Al}^{\mathrm{vi}}\right)\right] \leq 0.2$ and $\mathrm{Na} /(\mathrm{Na}+\mathrm{K}+\mathrm{Ca}) \leq 0.1$. Figure $6 \mathrm{~b}$ shows that, except for one tonalite sample (unit 1), all muscovites of the PMP have compositions typical of peraluminous granites following these criteria. However, chemical characteristics alone cannot determine if the muscovites from the PMP are of primary or secondary origin. Using the textural criteria outlined by Ham (1983), possible primary 
magmatic muscovite is observed in thin sections of the PMP, although Zen (1987) disputes the existence of an unambiguous textural basis for identifying magmatic muscovite.

Considerable overlap of muscovite chemistry among the three prominent units $(1,4,7)$ prevents separation on this basis, although unit 1 is the most chemically distinct. Three of the four muscovite samples from unit 1 have lower $\mathrm{Na} /$ $(\mathrm{Na}+\mathrm{K}+\mathrm{Ca})$ ratios and higher $\mathrm{Mg}$ and $\mathrm{Ti}$ compared with $\mathrm{Na}$ than any of the other units; this is in keeping with its tonalitic composition.

\section{Garnet}

Garnet from six samples has been analyzed, including four leucomonzogranites of unit 8 , one granodiorite from unit 1 , and one biotite schist country rock. Tables 2 and 3 briefly report the characteristics and chemistry, respectively, of the analyzed garnets. Three of the four garnets from unit 8 exhibit significant concentric zonation, with two of the samples displaying normal zonation profiles typified by $\mathrm{Ca}$ - and $\mathrm{Mn}$ rich cores and $\mathrm{Mg}$-rich rims.

Clarke (1981) listed possible origins of garnet in granitoid rocks: (1) refractory xenocrysts from porphyroblastic country rocks (Allan and Clarke, 1981); (2) refractory restite phase from the zone of partial melting (White and Chappell,
1977); (3) generation in marginal facies of a granite body as a result of reaction between magma and $\mathrm{Al}$ - and $\mathrm{Mn}$-rich pelitic xenoliths (Jamieson, 1974; Allan and Clarke, 1981); (4) nucleation directly from the silicate melt; and (5) reaction between early formed phases and silicate melt. According to Clarke (1981), normal zoning in the garnets is generally attributed to their growth in a metamorphic environment during prograde conditions while reverse zoning may indicate either growth during retrograde metamorphism or, in the case of igneous garnets, falling temperature and fractional crystallization.

Observations bearing on the origin of garnet in unit 8 include the following: (1) xenoliths are absent; (2) the spessartine content of the garnets is $>10 \%$, that is within the range for magmatic garnet (Miller and Stoddard, 1978); and (3) the garnets are normally zoned, a feature characteristic of prograde metamorphism of metasedimentary rocks (Kretz, 1973; Green, 1977). Observations bearing on the origin of garnet in unit 1 are: (1) abundance of garnet-rich xenoliths in the host granite; (2) low spessartine content compared to garnet in unit 8 , although it is still higher than the $10 \%$ range normally considered as magmatic (Miller and Stoddard, 1978); and (3) the garnets are inclusion-free, a feature common in igneous garnets. Thus, whereas the evidence would appear to favour a magmatic origin for most of the garnet in the PMP, there is

Table 2. Habit and alteration characteristics of garnet samples analyzed.

\begin{tabular}{|c|c|c|c|}
\hline $\begin{array}{c}\text { Sample + } \\
\text { (\# analyses) }\end{array}$ & Name & Habit + Abundance & Alteration \\
\hline $\begin{array}{l}\text { Unit } 8 \\
\text { NPM107 }\end{array}$ & & & \\
\hline$C=2, R=2$ & L MNZ & anhedral, $<1 \%$ & $\begin{array}{l}\text { core missing, gamet fractured moderate chloritization matrix } \\
\text { texture=cataclastic }\end{array}$ \\
\hline $\begin{array}{l}\text { NPM611 } \\
C=1, R=1\end{array}$ & L MNZ & subhedral, $<1 \%$ & minor chloritization, matrix subcataclastic, fracture garnet grains \\
\hline $\begin{array}{l}\text { NPM344 } \\
C=3, R=3\end{array}$ & L MNZ & subhedral, $<1 \%$ & some garnet grains fractured \\
\hline $\begin{array}{l}\text { NPM8A } \\
C=3, R=3\end{array}$ & L MNZ & anhedral, $<1 \%$ & garnet fractured, minor chloritization \\
\hline $\begin{array}{l}\text { Unit } 1 \\
\text { NPM484 } \\
G=3, R=3\end{array}$ & GRN & anhedral, $<1 \%$ & fractured, grains associated with chlorite. Gamets are inclusion free \\
\hline $\begin{array}{l}\text { NPM108 } \\
C=3, R=3\end{array}$ & $\begin{array}{l}\text { BIOTTTE } \\
\text { MUSCOVITE } \\
\text { SCHIST }\end{array}$ & euhedral, $5 \%$ & poikioblastic, unaltered \\
\hline
\end{tabular}

L MNZ - leucomonzogranite GRN - granodiorite

NPM108 - biotite muscovite schist (Meguma Group metasediment) 
Table 3. Chemistry of the garnets in the PMP and surrounding country rock.

\begin{tabular}{|c|c|c|c|c|c|}
\hline Sample & Name & $\begin{array}{c}\text { Almandine } \\
\text { Core:Rim }\end{array}$ & $\begin{array}{c}\text { Spessartine } \\
\text { Core:Rim }\end{array}$ & $\begin{array}{l}\text { Pyrope } \\
\text { Core:Rim }\end{array}$ & $\begin{array}{l}\text { Grossular } \\
\text { Core:Rim }\end{array}$ \\
\hline $\begin{array}{l}\text { NPM107 } \\
\text { NPM611 } \\
\text { NPM344 } \\
\text { NPM8A }\end{array}$ & $\begin{array}{l}\text { L MNZ } \\
\text { L MNZ } \\
\text { L MNZ } \\
\text { L MNZ }\end{array}$ & $\begin{array}{l}56.3: 59.1 \\
63.3: 64.5 \\
53.3: 60.8 \\
71.4: 68.9\end{array}$ & $\begin{array}{l}37.7: 35.3 \\
27.9: 27.2 \\
37.5: 30.4 \\
19.9: 23.5\end{array}$ & $\begin{array}{l}4.5: 4.3 \\
7.2: 6.6 \\
7.0: 6.8 \\
6.9: 5.9\end{array}$ & $\begin{array}{l}1.3: 1.2 \\
1.5: 1.6 \\
2.2: 2.0 \\
1.6: 1.6\end{array}$ \\
\hline NPM484 & GRN & $80.5: 78.4$ & $12.5: 15.1$ & $4.4: 3.7$ & $2.6: 2.8$ \\
\hline NPM108 & MEGUMA & $64.1: 63.9$ & $20.5: 21.4$ & $9.3: 8.8$ & $5.7: 5.8$ \\
\hline
\end{tabular}

\author{
L MNZ - leucomonzogranite \\ GRN - granodiorite \\ NPM108 - biotite muscovite schist (Meguma Group metasediment)
}

the possibility that some of the garnet represents xenocrysts probably inherited from the local country rock.

\section{Amphiboles}

Amphibole is only associated with the lamprophyre dykes (unit 5A) and corresponds to calcic amphibole. Analyses were made of amphibole samples from three zones within the lamprophyre dyke at Forbes Point lamprophyre, including: (1) phlogopite-amphibole-rich zone (predominant zone); (2) amphibole-rich zone occurring as lenses within the dyke; and (3) amphibole from the contact aureole (units 1 and 4). Zone 1 amphiboles are euhedral to subhedral, often contain minor inclusions of apatite and opaque minerals, have pale green pleochroism, and are frequently enveloped by large subhedral to euhedral phlogopite grains. Analyses indicate actinolitic compositions with two of the three grains analyzed showing core-to-rim zonation from actinolite to actinolitic hornblende. Zone 2 amphiboles are moss green, pleochroic, subhedral grains that are in a log-jam texture. Analyses indicate a magnesio-hornblende chemistry and in one sample an actinolitic hornblende core was overgrown by a magnesiohornblende rim. Zone 3 amphibole is moss green, anhedral with ragged rims, and appears to be in disequilibrium with nearby quartz. Compositions are magnesio-hornblende with two of these samples showing chemical zonation from an actinolitic core to a magnesio-hornblende rim.

Amphiboles in the MacLeods Cove lamprophyre occur in two habits, as anhedral to subhedral matrix minerals extensively replaced by phlogopite, or as concentrated clusters of subhedral to anhedral grains also altered to phlogopite; in both cases the amphiboles are pale-green and have poor crystal terminations. The amphiboles contain minor inclusions of sphene, apatite and opaque minerals. Compositionally the cores of the amphibole grains are actinolite whereas the rims are magnesio-hornblende.
In summary, the amphiboles from the PMP lamprophyres show a wide range in chemistry, ranging from ferroactinolite to actinolite and magnesio-hornblende. From both textural and chemical evidence the amphiboles appear to be of magmatic origin, whereas others appear to be subsolidus because of their poor crystal development and extensive phlogopitic alteration. Actinolite is considered to be a metamorphic mineral (Yamaguchi, 1985; Oba, 1980; Cameron, 1975; Deer et al., 1962), whereas hornblende can be of either metamorphic or igneous origin (Deer et al., 1966; Hammarstrom and Zen, 1986; Laird and Albee, 1981; Raase, 1974). In an attempt to determine the origin of the PMP amphiboles, their compositions were compared with metamorphic and magmatic amphibole fields defined by Jamieson (1981) (Fig. 6c), metamorphic hornblendes (mafic schists) from Vermont (Laird and Albee, 1981), and igneous hornblendes from five calc-alkaline plutonic complexes (Hammarstrom and Zen, 1986). While the amphibole data for the PMP fall in the metamorphic field based on the classification of Jamieson (1981), there is overlap based on the other data referred to above for magmatic and metamorphic amphiboles. For example, the magnesio-hornblendes and the actinolitic-hornblende of the Forbes Cove lamprophyre plot in (1) the field for high-pressure hornblendes in magmatic rocks based on the data of Hammarstrom and Zen (1986), (2) the metamorphic field defined by Jamieson (1981), and (3) the field of medium-pressure calcic-amphiboles in mafic schists (Laird and Albee, 1981). Thus, the amphibole chemistry suggests a possible combination of magmatic and post-magmatic processes which together account for the wide range in the observed compositions.

\section{Plagioclase}

Plagioclase is ubiquitous in all units, although its relative abundance varies both within and between units. The plagio- 
clase in the mafic end members (tonalites and granodiorites) of units 1,4 and 7 and the trondhjemite dyke of unit 2 is subhedral to anhedral and distinctly zoned $\left(\mathrm{An}_{42.18}\right)$; both normal and reverse zoning occur in any one sample (Fig. 6d). In these units, plagioclase occurs in the matrix (grain size 0.5$2 \mathrm{~mm}$ ) and occasionally as phenocrysts (grain size 2-6 mm).

Plagioclase in the more felsic members of units 4 and 7 and in units 3, 6, 8 and 9 occurs mainly in the matrix. Zoning is less distinct and anorthite compositions are lower $\left(\mathrm{An}_{9-23}\right)$ than in the mafic member described above. Some plagioclase in units $1,2,3$ and 7 show reverse zonation.

Plagioclase in the lamprophyres is the most calcic within the PMP and is distinctly zoned from cores $\left(\mathrm{An}_{23.57}\right)$ to rims $\left(A n_{25-35}\right)$. In the Forbes Point lamprophyre, plagioclase occurs as subhedral phenocrysts and anhedral groundmass, elements of which are more distinctly zoned and more calcic than plagioclase in the MacLeods Cove lamprophyre. Plagioclase in the MacLeods Cove lamprophyre is less calcic $\left(A n_{24}\right)$, but reverse zoning is present.

The anorthite composition of the plagioclase in the granitic phases (tonalite, granodiorite and monzogranite) decreases with decreasing plagioclase abundance and from mafic to felsic units (i.e., a decrease from units 1 to 3 ; a decrease from units 7 to 8 and 9 ). The anorthite compositions of plagioclase from the mafic granodiorite and tonalite end members of units 1 and 7 are similar.

Considerable disequilibrium is evident by the reverse zonation of the plagioclase, particularly in unit 1 . While several processes may result in the formation of reverse zoning, one mechanism involves increasing the temperature of the magma possibly through mixing of two melts of differing temperatures. Reversed zonation (although sporadic in abundance) is also apparent in the plagioclase of units 2,3 and 7 . This suggests that these units may also have resulted from commingling processes.

\section{Structural Features within the Port Mouton Pluton}

\section{Granitic Dykes and Joints in Granite}

Stereographic projection of 67 dyke orientations for units 4,7 and 8 (Fig. 5d) indicates that there is no single preferred orientation, although there is a predominance of moderately to steeply dipping dykes striking NW-SE. In contrast, stereographic projection of 183 orientations of unfilled joints in granite (Fig. 7a) generally shows a high proportion of subvertical joints with a northeasterly trend.

\section{Shear Zones and Shear Planes}

Shear planes and protomylonitic shear zones occur throughout the pluton in isolated 0.3 to $1.5 \mathrm{~m}$ wide zones. Evidence for ductile shearing has been observed in thin section and in hand specimen. Quartz grains have recrystallized into subgrains, quartz and feldspars have been elongated, and some micas are kinked. The shear zones appear to

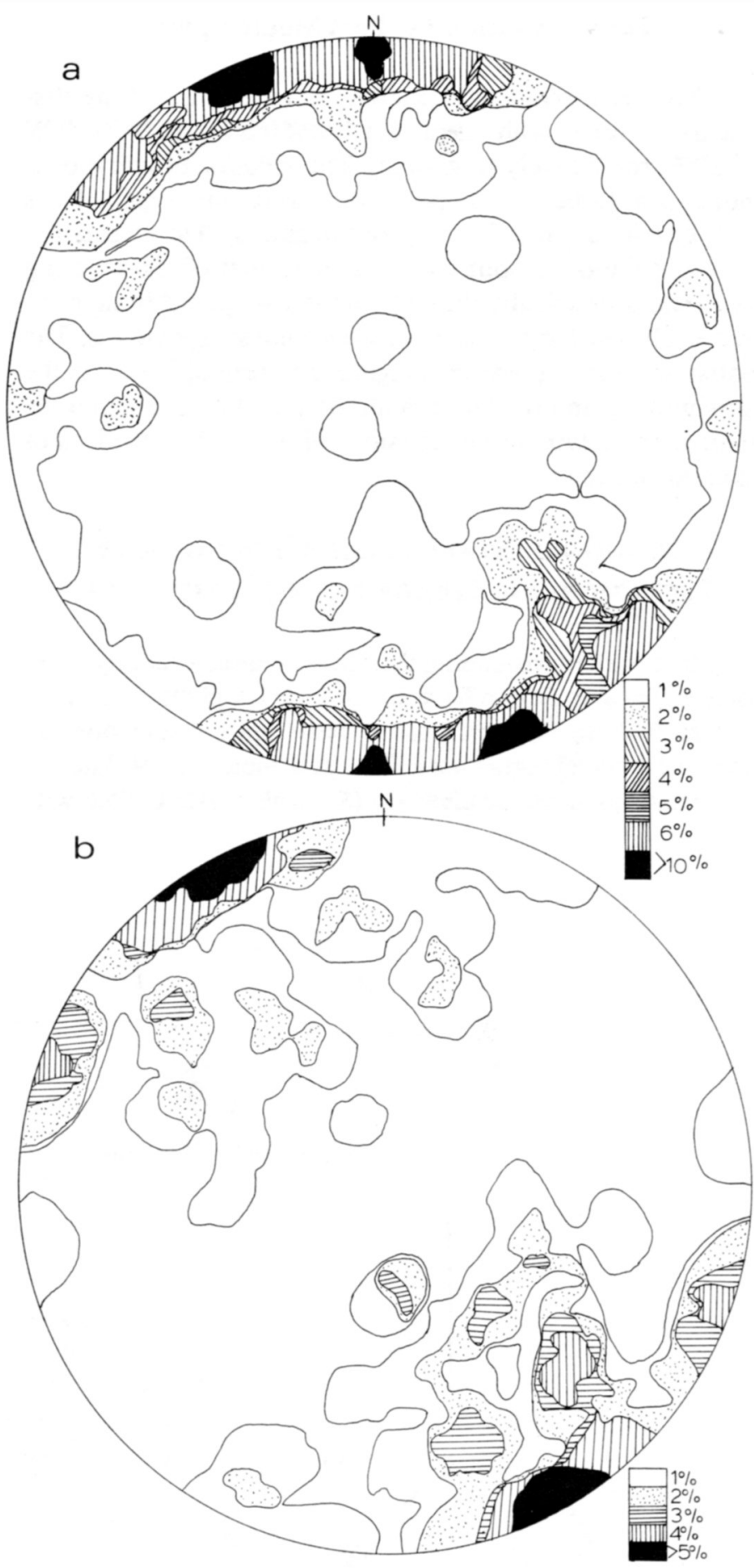

Fig. 7. Structural data (poles to planes) for different units of the Port Mouton pluton plotted in Schmidt stereographic projections. All diagrams contoured for $1 \%$ area. (a) 183 joints in granitoid rocks; (b) 69 shear zones and shear planes in granitoid rocks.

be uniformly distributed throughout the pluton, although north of Haley Lake, along Highway 103, entire granitic outcrops display in a $0.5 \mathrm{~km}$ wide zone a shear fabric trending $225^{\circ} / 66^{\circ}$ to $75^{\circ}$ to the west. A plot of 69 poles to these shear planes (Fig. 7b) clearly shows a strong preferred orientation at $060^{\circ} / 90^{\circ}$. 


\section{Foliation within the Port Mouton pluton}

The orientations of foliations in units 1 and 4 are distinctly different, with maxima at $108 \% 60^{\circ} \mathrm{SW}$ and $040^{\circ} / 70^{\circ} \mathrm{W}$ to $80^{\circ} \mathrm{E}$, respectively (Fig. $4 \mathrm{~b}, \mathrm{~d}$ ). The foliation of unit 4 does not appear to be superimposed on that of unit 1 (unit 1 has only one foliation defined by biotite grains). The orientation of the foliation of unit 4 is similar to that of the layering observed sporadically throughout the unit, possibly suggesting a relationship between these two physical features. The foliation in unit 1 may be magmatic in origin, based on the dissimilarity in orientation with the unit 4 foliation and the regional foliation (see discussion below), and by the lack of ductile deformation.

\section{Regional Structural Geology and Metamorphic Grade in the Host Rocks}

In the area surrounding the PMP, metasedimentary rocks of the Meguma Group have major $F_{1}$ folds plunging at $1^{\circ}$ to $16^{\circ}$ at $010^{\circ}$ to $045^{\circ}$ that range from upright and open to isoclinal; wavelengths vary from few meters to $10 \mathrm{~km}$. An associated axial planar cleavage $\left(S_{1}\right)$ strikes $012^{\circ}$ to $052^{\circ}$ with dips ranging from $70^{\circ} \mathrm{SE}$ to $70^{\circ} \mathrm{NW}$ (Hope and Woodend, 1986). It has also been noted that $S_{1}$ and $S_{0}$ are deflected by or deflected around the PMP in the St. Catherines River domain (Fig. 8). As well, in the Broad River-Western Head domain, $S_{0}$ is subparallel to the contact with the pluton, having been deflected $20^{\circ}$ to $30^{\circ}$ clockwise towards the east (Fig. 8).

The PMP has a concentric-shaped, 0.5 to $1 \mathrm{~km}$ wide, sillimanite-grade contact aureole that overprints a regional metamorphic assemblage composed of staurolite-cordieriteandalusite (Hope, 1987). The PMP occurs at the centre of a regional metamorphic culmination and it therefore appears that, rather than the pluton being responsible for the metamorphism, the metamorphism and plutonism may both be manifestations of locally increased thermal activity (Hope, 1987).

\section{Discussion and Conclusions}

The PMP, a complex intrusive body made up of at least ten distinct units, has been subdivided into a series of three mafic to felsic cycles based on field relationships. Further documentation of this subdivision based on chemical data is presented in Douma (1988), but is not discussed in this paper.

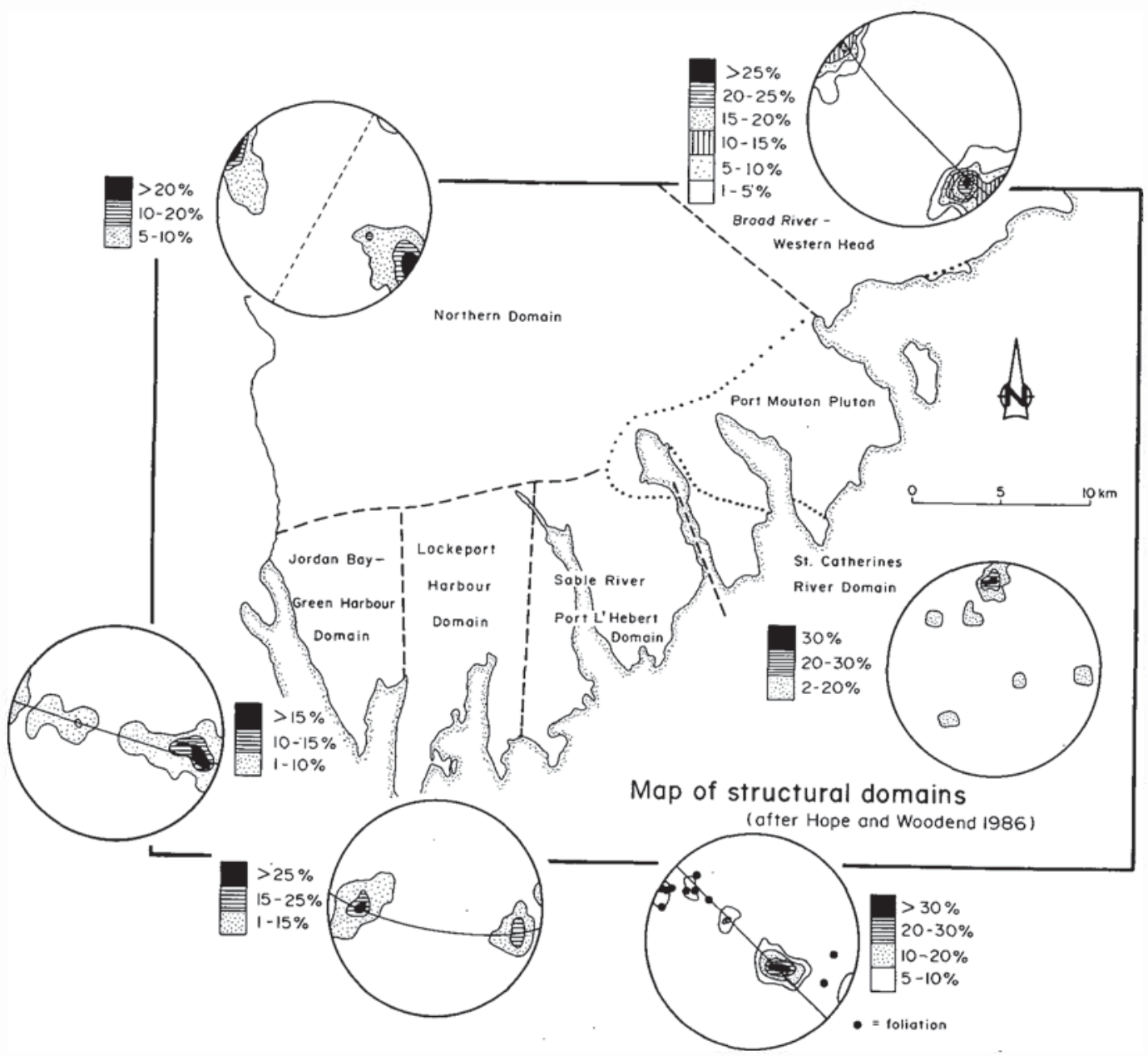

Fig. 8. Map of the structural domains surrounding the Port Mouton pluton with stereographic plots of bedding measurements recorded from within the domains (as mapped by Hope, 1987). 
These cycles consist of units 1 to 3 , units 4 to 6 and units 7 to 9. Unit 1 (the mafic end-member of cycle I) consists of a coarse- to medium-grained, foliated biotite tonalite and minor granodiorite. Unit 2 (a single trondhjemite dyke) crosscuts unit 1 whereas unit 3 , the felsic end-member of this first cycle, makes up only $1 \%$ of the pluton volumetrically and is a medium- to fine-grained, biotite-muscovite leucomonzogranite. The mafic end-member of cycle II is initiated by unit 4 , a medium-grained, biotite-muscovite granodiorite to monzogranite which constitutes $50 \%$ of the PMP. Unit 4 is cross-cut by the mafic lamprophyre dykes and tonalitic breccias of units 5A and 5B, respectively, which account for $<1 \%$ of the PMP. The felsic end-members of cycle II are the pegmatite, aplite and leucomonzogranites of unit 6 . The final cycle (cycle III) is initiated by the mafic end-member of unit 7 (5$10 \%$ of the PMP) which consists of fine-grained mesocratic to melanocratic biotite-muscovite tonalite, granodiorite and rarely monzogranite. This is the most compositionally diverse unit within the pluton. The felsic end-members of the cycle consist of biotite-muscovite leucomonzogranite (unit 8) and aplite and pegmatite dykes (unit 9), collectively accounting for $35 \%$ of the pluton.

Mineral chemistry of the major silicate phases indicate that continuums are present among the units and is consistent with a cogenetic relationship which is more firmly established with geochemical data (Douma, 1988). In addition, the peraluminous nature of the granitoids is reflected by the phyllosilicate chemistry and the presence of muscovite and garnet in some units. The presence of reverse zoning in plagioclase from many of the units suggests that commingling of mafic and felsic magmas may have occurred during the intrusive history of the PMP. The complex intrusive history established from mutual cross-cutting relations and sequence of three mafic-to-felsic cycles would be consistent with mixing of different magmas.

One of the most distinctive features of the PMP is the presence of two mafic phases, tonalites and lamprophyres, which are rarely observed elsewhere in the Meguma Terrane. The presence of these mafic rocks indicate that higher temperature parental melts than generally observed in, for example, the South Mountain Batholith, were present and may have been important in the petrogenetic evolution of the granites of the Meguma Terrane. The structural and metamorphic features of the country rocks and the structural features of the PMP itself are consistent with a depth of emplacement in excess of that of most other Meguma Terrane granites.

\section{ACKNOWLedgements}

Thanks are extended to Dr. D.B. Clarke of Dalhousie University who suggested the research topic, provided financial support and supervised the author. Thanks also to John Lerette who provided able field assistance and to Tracy Hope for the many discussions in the field. Daniel Kontak read an earlier draft of the paper which resulted in substantial changes and improvements, while Sandra Barr and John Hill are thanked for their critical and insightful reviews.
Allan, B.D. and Clarke, D.B. 1981. Occurrence and origin of garnets in the South Mountain Batholith, Nova Scotia. Canadian Mineralogist, 19, pp. 19-24.

Cameron, K.L. 1975. An experimental study of actinolite-cummingtonite phase relations with notes on the synthesis of $\mathrm{Fe}$ rich anthophyllite. American Mineralogist, 60, pp. 375-390.

Clarke, D.B. 1981. The mineralogy of peraluminous granites, a review. Canadian Mineralogist, 19, pp. 3-17.

Clarke, D.B. and Halliday, A.N. 1980. Sm/Nd isotopic investigation of the age and origin of the Meguma Zone metasedimentary rocks. Canadian Journal of Earth Sciences, 22, pp. 102-107.

Cormier, R.F. and Smith, T.E. 1973. Radiometric ages of granitic rocks, southwestern Nova Scotia. Canadian Journal of Earth Sciences, 10, pp. 1201-1210.

Dallmeyer, R.D. and Keppie, J.D. 1986. Polyphase Late Paleozoic tectono-thermal evolution of the Meguma Terrane, Nova Scotia. Abstracts with Programs, Northeastern Section, Geological Society of America, 18, p. 11.

De Albuquerque, C.A.R. 1977. Geochemistry of the tonalitic and granitic rocks of the Nova Scotia Southern plutons. Geochimica et Cosmochimica Acta, 41, pp. 1-13.

Deer, W.A., Howie, R.A., and Zussman, J. 1962. Rock-Forming Minerals, 3, Sheet Silicates. Longmans, Green and Company, Limited.

- 1966. An Introduction to the Rock Forming Minerals. Longman Group Limited.

Douma (Woodend), S.L. 1988. The Mineralogy, Petrology and Geochemistry of the Port Mouton Pluton, Nova Scotia, Canada. Unpublished M.Sc. thesis, Dalhousie University, Halifax, Nova Scotia.

Elias, P. 1986. Thermal History of the Meguma Terrane: A study based on ${ }^{40} \mathrm{Ar}-{ }^{39} \mathrm{Ar}$ and Fission Track Dating. Unpublished Ph.D. thesis, Dalhousie University, Halifax, Nova Scotia.

Fairbairn, H.W., Hurley, P.M., Pinson, W.H., and Cormier, R.F. 1960. Age of the granitic rocks of Nova Scotia. Geological Society of America Bulletin, 71, pp. 399-414.

Fairbault, E.R. 1913-14. Geology of the Port Mouton Map Area, Queens County, Nova Scotia. Geological Survey of Canada, Summary Report 1913-14.

Green, T.H. 1977. Garnet in silicic liquids and its possible use as a P-T indicator. Contributions to Mineralogical and Petrology, 65, pp. 59-67.

НА, L. 1983. Determination of chemical composition of different types of white mica within Nova Scotia Granites. Unpublished Internal Report, Department of Geology, Dalhousie University, Halifax, Nova Scotia.

Hammarstrom, J.M. and Zen, E-An. 1986. Aluminum in homblende: An empirical igneous geobarometer. American Mineralogist, 71, pp. 1297-1313.

Hope, T.L. 1987. Geology and Metamorphism in the Port MoutonLockeport Area, Queens and Shelburne Counties, Nova Scotia. Unpublished M.Sc. thesis, Acadia University, Wolfville, Nova Scotia.

Hope, T.L. and Woodend, S.L. 1986. Geological mapping and igneous and metamorphic petrology, Queen's and Shelburne counties, Nova Scotia. In Current Research, Part A, Geological Survey of Canada, Paper 86-1A, pp. 429-433.

JAmieson, R.A. 1974. The contact of the South Mountain Batholith Near Mount Uniacke, Nova Scotia. Unpublished B.Sc. thesis, Dalhousie University, Halifax, Nova Scotia.

1981. Metamorphism during ophiolite emplacement. The petrology of the St. Anthony Complex. Journal of Petrology, 
22. pp. $397-449$.

KRETZ, R. 1973. Kinetics of the crystallization of garnet at two localities near Yellowknife. Canadian Mineralogist, 12, pp. $1-20$.

KUbilius, W.P. 1983. Sulfur Isotopic Evidence for Country Rock Contamination of Granitoids in Southwestern Nova Scotia. Unpublished M.Sc. thesis, Pennsylvania State University.

Laird, J. and Albee, A.L. 1981. Pressure, temperature and time indicators in mafic schist: Their application to reconstructing the polymetamorphic history of Vermont. American Journal of Science, 281, pp. 127-175.

Longstraffe, F.J., Smith, T.E., and Muehlenbachs, K. 1979. Oxygen isotope evidence for the genesis of upper Paleozoic granitoids of southwestern Nova Scotia. Canadian Journal of Earth Sciences, 17, pp. 132-141.

MacDonald, D. 1988. Examination of a zoned Pegmatite and Host Rocks at Port Joli Nova Scotia. Unpublished B.Sc. thesis, Dalhousie University, Halifax, Nova Scotia.

MAKsaev, V. 1986. The origin of banding in the Mountain Island Granite, Southern Nova Scotia. Unpublished Internal Report, Dalhousie University, Halifax, Nova Scotia.

Merrett, D. 1987. The migmatites of Port Mouton. Unpublished B.Sc. thesis, Dalhousie University, Halifax, Nova Scotia.

Miller, C.F. and Stoddard, E.F. 1978. Origin of garnet in granitic rocks; an ex ample of the role of $\mathrm{Mn}$ from the WomanPiute Range, California. Geological Association of Canada Mineralogical Association of Canada, Program with Abstracts, 3, p. 456.

Ов А, Т. 1980. Phase relations in the tremolite-pargasite join. Contributions to Mineralogy and Petrology, 71, pp. 247-256.

Oldale, H.R. 1959. Beryllium, Port Mouton, Queens County, Nova Scotia. Preliminary Report, Nova Scotia Department of Mines, 20P/15C 08-N-18 (01).
RAASE, P. 1974. Al and Ti contents of homblende Indicators of pressure and temperature of regional metamorphism. Contributions to Mineralogy and Petrology, 45, pp. 231-236.

Reynolds, P.H., Zentilli, M., and Muecke, G.K. 1981. K-Ar and ${ }^{40} \mathrm{Ar} /{ }^{39} \mathrm{Ar}$ geochronology of granitoid rocks from southern Nova Scotia: its bearing on the geological evolution of the Meguma Zone of the Appalachians. Canadian Journal of Earth Sciences, 18, pp. 386-394.

SMITH, T.E. 1979. The geochemistry and origin of the Devonian granitic rocks of southwest Nova Scotia. Geological Society of America Bulletin, 90, pp. 850-885.

Stallard, V. 1975. Geochemistry of biotites as a guide to the evolution of the South Mountain Batholith. Unpublished B.Sc. thesis, Dalhousie University, Halifax, Nova Scotia.

Streckeisen, A. 1976. To each plutonic rock its proper name. Earth Science Reviews, 12, pp. 1-33.

TAYLOR, F.C. 1967. Reconnaissance geology of Shelburne maparea, Nova Scotia. Geological Survey of Canada, Memoir 349.

Trent, D.D. 1981. Schlieren in the Sierra Nevada. Paper presented at the 77th Annual Meeting of the Geological Society America, March 27, Sonora, New Mexico.

VerNon, R.H. 1984. Microgranitoid enclaves in granite globules of hybrid magma quenched in a plutonic environment. Nature, p. 309.

White, A.J.R. and Chappel, B.W. 1977. Ultrametamorphism and granitoid genesis. Tectonophysics, 43, pp. 7-22.

YAMAGUCHI, Y. 1985. Hornblende-cummingtonite and hornblendeactinolite intergrowths. American Mineralogist, 70, pp. 980 986.

ZEN, E-AN. 1987. Phase relations of peraluminous granitic rocks and their petrogenic implications. Earth Science Reviews, p. 24. 